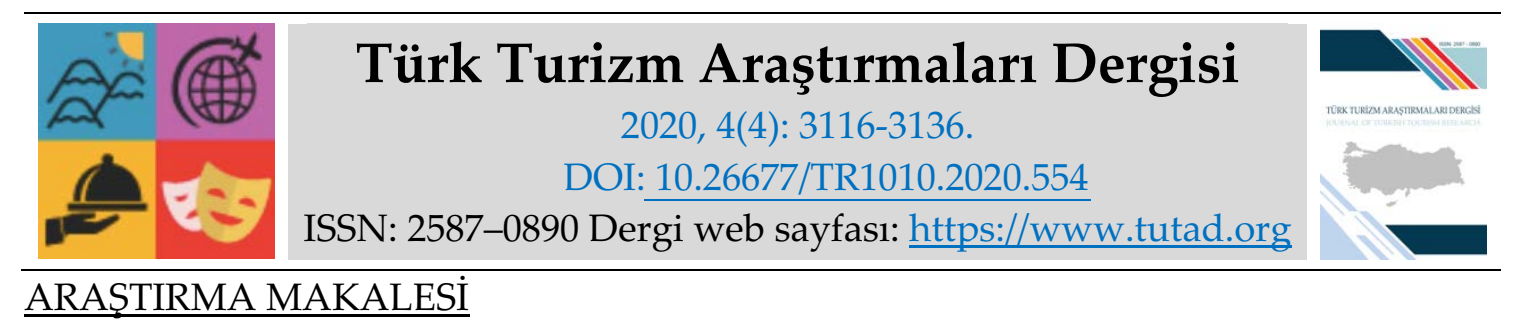

\title{
Covid-19 Salgınının Turizm Sektörüne Etkilerinin ve Uygulanan Stratejilerin Değerlendirilmesi: Otel Yöneticileri Üzerinde Bir Araştırma
}

Prof. Dr. Erdinç KARADENIZ, Mersin Üniversitesi Turizm Fakültesi, Mersin, e-posta: ekaradeniz@mersin.edu.tr ORCID: https://orcid.org/0000-0003-2658-8490

Fatma Senem BEYAZ, Doktora Öğrencisi, Mersin Üniversitesi, Sosyal Bilimler Enstitüsü, Mersin, e-posta:senembyz@hotmail.com ORCID: https://orcid.org/0000-0001-7895-8006

Sema Nur ÜNLÜBULDUK, Doktora Öğrencisi, Mersin Üniversitesi, Sosyal Bilimler Enstitüsü, Mersin, e-posta:unlubulduksemanur@hotmail.com ORCID: https://orcid.org/0000-0002-8973-8305

Öğr. Gör. Eda KAYHAN, Çağ Üniversitesi, İktisadi ve İdari Bilimler Fakültesi, Adana, e-posta: edakayhan@cag.edu.tr ORCID: https://orcid.org/0000-0001-5033-5579

\section{Öz}

$\mathrm{Bu}$ araştırmanın temel amacı, otel yöneticilerinin Covid-19 salgınının turizm sektörü üzerinde makro düzeydeki etkilerine ilişkin düşüncelerinin ve otel işletmelerine yönelik mikro düzeydeki beklentilerinin ve önerilerinin değerlendirilmesidir. Bu amaçla sekiz açı uçlu soru şeklinde oluşturulan online anket formu, elektronik ortamda farklı pozisyonlardaki otel yöneticilerine gönderilmiştir. Yanıt alınan 103 adet anket içerik analizine tabii tutulmuştur. Analiz sonucunda salgının turizm sektörü üzerindeki en büyük etkilerinin yüksek gelir ve istihdam kaybı olacağı belirlenmiştir. Ayrıca otel işletmelerinin en çok Sağlık Bakanlığı ile Kültür ve Turizm Bakanlığı tarafından yayımlanan genelgeler doğrultusunda önlemler aldıkları ve çalışanlarına salgınla ile ilgili eğitim verdikleri tespit edilmiştir. Buna karşın salgının yayılması ihtimaline karşı otel işletmelerinin bir kısmının alternatif plana sahip olmadıkları saptanmıştır. Yine işletmelerin devletten özellikle vergi indirimi ile kısa çalışma ödeneği gibi destekler bekledikleri saptanmıştır. Araştırma sonucunda otel yöneticileri tarafından en sık yapılan önerilerin güvenli ülke imajına yönelik pazarlama çalışmalarının yapılması ve nitelikli işgücünün korunması olduğu tespit edilmiştir.

Anahtar Kelimeler: Covid-19 Salgını, Turizm Sektörü, Otel İşletmeleri, Otel Yöneticileri.

Makale Gönderme Tarihi: 26.06.2020

Makale Kabul Tarihi: 03.10.2020

Önerilen Atıf:

Karadeniz, E., Beyaz, F. S., Ünlübulduk, S. N. ve Kayhan, E. (2020). Covid-19 Salgınının Turizm Sektörüne Etkilerinin ve Uygulanan Stratejilerin Değerlendirilmesi: Otel Yöneticileri Üzerinde Bir Araştırma, Türk Turizm Araştırmaları Dergisi, 4(4): 3116-3136.

(C) 2020 Türk Turizm Araştırmaları Dergisi. 


\title{
Journal of Turkish Tourism Research
2020, 4(4): $3116-3136$. \\ RESEARCH PAPER
}

\section{Evaluation of the Impacts of Covid-19 Pandemic on Tourism Sector and the Applied Strategies: A Research on Hotel Managers}

Prof. Dr. Erdinç KARADENIZ, Mersin University Faculty of Tourism, Mersin, e-mail: ekaradeniz@mersin.edu.tr ORCID: https://orcid.org/0000-0003-2658-8490

Fatma Senem BEYAZ, Ph.D, Student, Mersin University, Faculty of Economics and Administrative Sciences, Mersin, e-mail:senembyz@hotmail.com

ORCID: https://orcid.org/0000-0001-7895-8006

Sema Nur ÜNLÜBULDUK, Ph.D, Student, Mersin University, Faculty of Economics and Administrative Sciences, Mersin, e-mail:unlubulduksemanur@hotmail.com

ORCID: https://orcid.org/0000-0002-8973-8305

Lecturer Eda KAYHAN, Çă̆ University, Faculty of Economics and Administrative Sciences, Adana, e-mail: edakayhan@cag.edu.tr

ORCID: https://orcid.org/0000-0001-5033-5579

\begin{abstract}
The main aim of this research is to evaluate the opinions of hotel managers regarding the macro-level effects of Covid-19 pandemic on the tourism sector and their micro-level expectations and suggestions for hotel companies. For this purpose, an online questionnaire, which was created in the form of eight open-ended questions, was sent electronically to hotel managers in different positions. 103 questionnaires that were answered were subjected to content analysis. As a result of the analysis, it was determined that the greatest effects of the epidemic on the tourism sector will be high income and employment loss. In addition, it has been determined that the hotel companies mostly take measures in line with the circulars issued by the Ministry of Health and the Ministry of Culture and Tourism, and provided training to the employees about the epidemic. However, it was determined that some of the hotel enterprises did not have an alternative plan in case the outbreak spread. Again, it has been determined that businesses expect support from the state, especially tax reduction and short-time working allowance. Making marketing efforts to secure the country's image and to protection of the qualified labor force were the most frequently recommendations by hotel managers.
\end{abstract}

Keywords: Covid-19 Pandemic, Tourism Sector, Hotel Companies, Hotel Managers.

Received: 26.06 .2020

Accepted: 03.10.2020

Suggested Citation:

Karadeniz, E., Beyaz, F. S., Ünlübulduk, S. N. and Kayhan, E. (2020). Evaluation of the Impacts of Covid-19 Pandemic on Tourism Sector and the Applied Strategies: A Research on Hotel Managers, Journal of Turkish Tourism Research, 4(4): 3116-3136.

(C) 2020 Türk Turizm Araştırmaları Dergisi. 


\section{Gíriş}

Tarihsel süreç içerisinde salgın hastalıkların türü ve yaygınlığındaki değişiklikler, avcılık ve göçebe yaşamdan yerleşik hayata geçişte ya da sanayi devrimi sonucunda oluşan kentleşmeyle birlikte hız kazanmıştır. Salgın hastalıkların yakın zamanda yeniden ortaya çıkmasının, hızla büyüyen hareketli bir dünya nüfusu, gelir artışı, kentleşme eğilimleri ve ekolojik bozulmadan kaynaklandığı düşünülmektedir (Pongsiri vd., 2009: 945). Gelir artışı, gelişmekte olan ülkelerde artan hayvansal protein tüketimi ile ilişkilendirilmektedir. Bu bağlamda gelirde meydana gelen artışla birlikte hayvanlardan insanlara geçen hastalıkların ortaya çıkma olasılığı yükselmektedir. Kentleşme, insanların daha fazla bir arada vakit geçirmesi ve daha yakın ilişkiler kurması anlamına gelmektedir. Bu durum yeni salgın hastalıkların yayılma riskini artırmaktadır. Küreselleşmeyle beraber ticaret ve seyahatin gelişmesi ise ülkeler arasında salgın hastalıkların yayılmasını kolaylaştırmaktadır (Wu vd., 2016: 2).

Yirminci yüzyılda genel bağlamda üç büyük salgın yaşandığı kabul edilmektedir. Bunlardan ilki 1918-1919 yıllarında yaşanan İspanyol gribidir. 1. Dünya Savaşı sırasında ve sonrasında milyonlarca askerin hareketliliği ile yaklaşık 500 milyon insana bulaşan bu hastalık, dünya nüfusunun dörtte birinin hastalanmasına neden olmuştur. Sonrasında 1957-1958 yıllarında yaşanan Asya gribi ve 1968 yılında yaşanan Hong Kong gribi kısa sürede yayılarak yaklaşık birer milyon insanın ölümüne sebep olmuştur. Yirmi birinci yüzyılda ise insanlığı etkileyen beş büyük salgının gerçekleştiği görülmektedir. Bunlardan ilki, 2002 yılında ortaya çıkmıştır. İlk olarak canlı hayvan pazarı çalışanlarında görülen ağır akut solunum yolu yetersizliği sendromu (SARS), 29 ülkeye yayılarak 8000 insanı etkisi altına almıştır. Uluslararası ticaret ve seyahatin artmasıyla birlikte 2009 yılında domuz gribi, 2012 yılında yaşanan Ortadoğu solunum sendromu (MERS) ve 2013 yılında Ebola gribi, salgına dönüşerek birçok ülkeye yayılmış ve binlerce insanın ölümüne sebep olmuştur (Taubenberger ve Morens 2006; Greger, 2007; Coker vd., 2011; Wu vd., 2016; Gössling vd., 2020). Yirmi birinci yüzyılın beşinci büyük salgını ise Çin Halk Cumhuriyeti'nin 2019 yılı Aralık ayının sonlarında Hubei Eyaleti Wuhan şehrinde bulunan deniz ürünleri ve hayvan pazarına uğramış insanların hastanelere başvurmasıyla kendini gösteren Yeni Koronavirüs Hastalığı (Covid-19) olarak 7 Ocak 2020'de tanımlanmıştır. Hastaneye başvuran insanlarda ateş, nefes darlığı ve öksürük gibi solunum yolu belirtilerinin geliştiği gözlemlenmiştir. Başlangıçta sadece Wuhan şehrinde görülen hastalık, sonrasında eyaletteki diğer şehirlere ve ardından tüm dünyaya yayılarak salgına dönüşmüştür (T.C. Sağlık Bakanlığı COVID-19 Rehberi, 2020). Dünya Sağllk Örgütü, 11 Mart 2020 durum raporunda Covid-19'u bir salgin olarak ilan etmiştir (WHO, 2020).

İnsanlık tarihinde yaşanan tüm salgınlar gibi Covid-19'da dünya için büyük bir sağlık problemi olmanın yanı sıra, birçok toplumsal ve ekonomik soruna yol açmıştır. Salgından kaynaklı insan kaybının önüne geçmek isteyen ülkeler, insan hareketliliğini azaltmak için seyahat kısıtlamaları, sokağa çıkma kısıtlamaları, maske kullanma zorunluluğu, sosyal mesafe (insanlar arası fiziksel mesafe) ve karantina tedbirleri almak durumunda kalmıştır. Bu tür uygulamalar ekonomik olarak üretim ve tüketimi olumsuz etkileyerek ekonomik faaliyetlerin yavaşlamasına sebep olmuş ve küresel bağlamda ekonomik durgunluğa (resesyon) yol açmıştır (TÜRSAB, 2020:4). Uluslararası Para Fonu (IMF), 2020 yılı için dünya ekonomisinde \%3,3’lük bir daralma beklerken, salgının küresel ekonomide yaratacağı daralma etkisinin, 1930'larda yaşanan Büyük Buhran'dan bu döneme kadarki en büyük düşüş olabileceğini ifade etmiştir. Bununla birlikte söz konusu etkinin en çok gelişmekte olan ülkelerde hissedileceği ve yüz milyarlarca dolar desteğe ihtiyaç duyulacağı belirtilmiştir (www.bcc.com).

Dünya üzerinde birçok sektörü doğrudan etkileyen salgın, seyahat kısıtlamaları nedeniyle en büyük etkiyi turizm sektörü üzerinde göstermiştir. Benzeri görülmemiş küresel seyahat 
kısıtlamaları ile sokağa çıkma yasaklarının, 2. Dünya Savaşı'ndan bu yana küresel ekonominin en büyük dalgalanmayı yaşamasına neden olacağı düşünülmektedir. Dünya nüfusunun \%90'ından fazlasını etkileyen uluslararası seyahat yasakları ve topluluk hareketliliği üzerindeki geniş çaplı kısıtlamalar sonucunda turizm hareketliliği Mart 2020'de büyük ölçüde yavaşlatılmıştır (Gössling vd., 2020:1). Birleşmiş Milletler Dünya Turizm Örgütü'nün (UNWTO) verilerine göre 27 Nisan 2020 tarihi itibariyle dünya çapında 217 destinasyonun 156 tanesinde (\%72) uluslararası turizm tamamen durdurulmuştur. Avrupa'daki destinasyonların \%83'ü uluslararası turizm için sınırlarını tamamen kapatmışken, Amerika'da bu oran \%80, Asya ve Pasifik'te \%70, Orta Doğu'da \%62 ve Afrika'da \%57 olarak gerçekleşmiştir. Başta Asya Pasifik bölgesi olmak üzere tüm dünya genelinde turizm gelirlerinde 80 milyar dolarlık bir kayıp yaşanmıştır (www.unwto.org). Dünya Seyahat ve Turizm Konseyi (WTTC), salgın sonucunda küresel ölçekte turizm sektörünün dünya gayrisafi milli hasılaya olan katkısının 2,7 trilyon dolar azalacağını, sektörün küresel bağlamda yaratacağı istihdam alanındaki iş kayıplarının ise 100,8 milyon kişi olacağını öngörmektedir (www.wttc.org). Uluslararası Hava Taşımacıllğı Birliği (IATA) tarafından açıklanan verilere göre, 2020 yılında yolcu gelirlerinin 2019 yılına göre 252 milyar dolar daha düşük gerçekleşeceği ve yolcu kilometre değerinin yıllık bazda \%38 düşeceği tahmin edilmektedir. IATA, birçok havayolu şirketinin üç aydan daha az bir süre yetecek likiditeye sahip olduğunu ve bu şirketlerin uzun bir hava taşımacılığı kısıtlaması süresinden sonra faaliyetlerine devam edemeyeceklerini bildirmektedir (www.iata.org). Uluslararasi Havalimanları Konseyi tarafından yayımlanan rapora göre de devam eden krizle 2020 yılının sonuna kadar yaklaşık 76 milyar doların üzerinde bir kayıp yaşanması beklenmektedir (Airports Council International, 2020:6). Otel işletmelerinin önemli bir k1smı ise salgin sürecinde kapalıyken ya da önemli ölçüde daha düşük sayıda turisti ağırlarken, 2020 sektör gelir tahminleri önemli seviyede düşüşs olacağını göstermektedir. Türkiye Otelciler Birliği (TÜROB) iş birliği ile hazırlanan otel doluluk verilerine göre, Mart 2020'de dünyadaki otel işletmelerinin doluluk oranlarında büyük bir düşüş gözlemlenmiştir. Avrupa'da Mart 2020'de görülen \%26,3'lük doluluk oranı ile Avrupa, 2. Dünya Savaşı'ndan günümüze kadar geçen sürede en düşük seviyeyi görmüştür (www.turob.com.tr). Bunun yanı sıra turizm sektöründe faaliyet gösteren seyahat acenteleri ve tur operatörleri en büyük zarar gören kesimlerden biri olarak dikkat çekmektedir. 2019 yılı sonunda otel işletmelerine oda ve hava yolu işletmelerine koltuk bedellerini önceden ödeyen işletmeler, salgın sebebiyle gerçekleştirdikleri satışları iptal etmek ya da ertelemek durumunda kalmıştır (TÜRSAB, 2020: 23). Salgının yönetilmesi için birçok ülkede uygulanan sosyal mesafe ve sokağa çıkma kısıtlamaları, yiyecek içecek işletmelerinin de geçici olarak kapatılmalarına sebep olmuştur. Söz konusu işletmelerin, havayolu işletmeleri gibi sınırlı likiditeye sahip oldukları için uzun vadede bu durumdan oldukça zararlı çıacakları tahmin edilmektedir (Gössling vd., 2020:12).

Turizm, çok yönlü yapısı ve alt sektörleriyle birlikte ele alındığında bir ülkenin dış ticaret dengesini, ticari faaliyetlerini, döviz kazancını ve istihdam oranını artırmada önemli bir rol oynamaktadır. Ülkelerin ekonomik kalkınmasında büyük ölçüde paya sahip olan turizm sektörü, sosyal ve politik faktörlerden doğrudan etkilenmektedir (Kalyankar ve Patil, 2020: 611). Küresel turizmin ve bireysel destinasyonların pazarlanabilirliği, piyasa algılarındaki ani değişimlere karşı savunmasız kalabilmektedir. Sosyal, siyasal ve ekonomik krizler ile yukarıda ifade edildiği gibi yaşanabilecek salgın hastalıklar en popüler turizm destinasyonlarının itibarını ve tercih edilebilirliğini bir gecede değiştirebilmektedir. Günümüzde dünyada turistik bir varış yerinin tercih edilebilirliğini tehlikeye atan olaylar, bölgede ve ülkede önemli ölçüde ekonomik sorunlara neden olabilmektedir. Bireyler için bu durum gelir kaybına, işsizliğe ve yoksulluğa yol açmaktadır. 1991 Körfez Savaşı, 11 Eylül 2001'de New York'da düzenlenen terör saldırıları, ağır akut solunum yolu sendromu (SARS), orta doğu solunum sendromu (MERS) ve daha birçok vaka, bir ülkedeki krizin küresel olarak dalgalanma etkisi olduğunu göstermektedir (Beirman, 
2003:3-4). Terörizm, doğal afetler ve politik krizlerin süresine kıyasla salgın hastalıklardan kaynaklanan krizlerin turizm sektörü üzerine etkisi farklılık gösterebilmektedir. Mevcut veriler, destinasyon bölgelerinin salgın hastalık krizlerinden kurtulma süresinin genellikle 12 ila 34 ay arasında olduğunu göstermektedir. Bununla birlikte turizmde iyileşme süresi, yaşanan salgın hastalıklardaki vaka sayısı ile paralel bir şekilde seyir etmektedir. Örneğin, Ebola salgınından 35 ay sonra bile Sierra Leone'ye uluslararası varışlar, salgın öncesi ziyaretçi sayısının \%50'sinin altında kalmıştır. Benzer şekilde Hong Kong'da SARS salgını sebebiyle turizm talebinde iki çeyreklik bir dönemde keskin bir düşüş yaşanmıştır. İngiltere'de 2001 yılında görülen el-ayakağız hastalığı ise turizm sektörünün büyümesini durdurmuş ve büyüme oranları iki yıl boyunca salgından önceki seviyesinde kalmıştır (Khalilzadeh, 2020:2).

Bütün dünyada etkisini gösteren Covid-19 salgınına karşı dünya devletleri, söz konusu süreci yönetebilmek amacıyla kendi önlemlerini almakta ve çözüm önerileri geliştirmeye çalışmaktadır. Türkiye'de 4 Mayıs 2020 tarihi itibariyle Sağlıklı Turizm Sertifikasyon Programı süreci tamamlanmıştır. Türkiye'nin Sağlıklı Turizm Sertifikasyon Programı, "tatilini Türkiye'de geçirecek tüm Türk vatandaşları ve yabancı ziyaretçilere, ulaşımdan konaklamaya, tesis çalışanlarından yolcuların kendi sağlık durumuna uzanan geniş bir yelpazede alınması önerilen bir dizi tedbiri tanımlamaktadır"'(www.tga.com.tr). Sektörde faaliyet gösteren işletmeler için isteğe bağlı olarak başvurulabilen Sağlıklı Turizm Sertifikasyon Programı, dünyadaki sayılı örneklerden biridir. Program, Kültür ve Turizm Bakanlığı'nın liderliğinde, Sağlık, Ulaştırma, İçişleri ve Dışişleri Bakanlıklarının katkıları ve sektör paydaşlarının iş birliğiyle hazırlanmıştır. Sertifika, yolcu sağlığı ve güvenliği, çalışan sağlığı ve güvenliği, tesislerde alınan önlemler ve ulaşım araçlarında alınan önlemler olmak üzere dört ana başlık altında hazırlanmıştır. Sertifikasyonu alan tesisler, oluşturulan kriterler çerçevesinde denetlenmekte, yetkili akreditasyon firmaları hijyen ve sağlık denetimi ile uygunluk değerlendirmesi yaparak söz konusu durumlara ilişkin raporlar düzenlemektedir.

$\mathrm{Bu}$ araştırmada, Türk turizm sektöründe faaliyet gösteren otel işletmelerinde farklı pozisyonlarda görev yapmakta olan yöneticilerinin, Covid-19 salgınının Dünya ve Türk turizm sektörü üzerindeki etkilerine ilişkin düşüncelerinin ve sektörde faaliyet gösteren otel işletmelerine yönelik öngörülerinin, beklentilerinin ve önerilerinin değerlendirilmesi amaçlanmıştır. Araştırma, belirlenen amaçlara yönelik olarak dört bölümden oluşmaktadır. İlerleyen bölümde dünyada yaşanan salgınların ve Covid-19'un turizm sektörüne etkisi bağlamında daha önce gerçekleştirilen araştırmalar özetlenmiştir. Bir sonraki bölümde çalışmanın veri kaynakları ve kullanılan analiz yöntemi açıklanmıştır. Daha sonra gerçekleştirilen analiz sonucunda elde edilen bulgular sunulmuştur. Araştırmanın son bölümünde ise analiz sonucunda elde edilen bulgular bağlamında genel bir değerlendirme yapılarak öneriler sunulmaya çalışılmıştır.

\section{LITERATÜR}

Turizm, çok çeşitli ağlardan oluşan karmaşık bir sistemdir. Bu durum, çeşitli katmanlardaki küresel, iç içe geçmiş yerel ağların birbirleriyle etkileşim içerisinde olduğunu ifade etmektedir. Bunun yanında turizm, içinde bulunduğu çevre ile malzeme, enerji ve bilgi alışverişinde bulunan açık bir sistemdir. Turizm sektörünün doğası, söz konusu devasa karmaşık sistemi küresel ve yerel ekonomik ve sağlik sistemleri gibi diğer birçok sistemle temas halinde olmasına neden olmaktadır. Yapısal olarak, bu kombinasyon ve davranış, turizm sektörünü krizlere, doğal afetlere, terör saldırılarına ve salgın hastalıklara karşı aşırı duyarlı hale getirmektedir (Khalilzadeh, 2020). Literatür incelendiğinde, salgın hastalıkların turizm sektörüne yönelik etkilerine ilişkin araştırmaların gerçekleştirildiği gözlemlenmiştir. 
Kuo vd., (2008), çalışmalarında SARS ve Kuş Gribi salgınlarının uluslararası turizm talebi üzerindeki etkilerini ölçmeyi amaçlamışlardır. Bu bağlamda Asya ülkelerine gelen turist sayıları incelenmiştir. Asya'daki SARS salgınını yaşayan Çin, Hong Kong, Singapur, Tayvan ile Kuş Gribini yaşayan Endonezya ve Vietnam için aylık verilerle zaman serisi analizi yapılmıştır. Ayrıca SARS ve Kuş Gribinin, salgını yaşayan ülkeler üzerindeki bölgesel turizm etkilerini ölçmek için dinamik panel veri analizi gerçekleştirilmiştir. Analiz sonucunda Asya ülkelerindeki turizm talebinin Kuş Gribi'nden önemli ölçüde etkilenmediği buna karşın SARS'ın olumsuz etkilerinin daha büyük ve kalıcı olduğu tespit edilmiştir. Araştırmada ayrıca SARS salgının dört ülkedeki turizm talebinde yarattığı değişimlerin hükümet politikaları bağlamında farklılık gösterdiği saptanmıştır.

Page vd., (2012), domuz gribi salgınının ve ekonomik krizin Birleşik Krallık'ta bulunan 14 turizm destinasyonuna olan turizm talebi üzerindeki etkisini incelemişlerdir. Araştırma sonucunda, domuz gribi salgınının turizm talebini 14 destinasyonun tamamında olumsuz etkilediği görülmüş̧tür. 2009 yılında domuz gribinin belirli bir dönem içinde, ekonomik krizin yerini alarak Birleşik Krallık'a olan turizm talebini etkileyen ana kriz olduğu tespit edilmiştir. Araştırmada ayrıca domuz gribi salgınının sonrasında Çin, İspanya, Güney Kore ve Rusya'dan gelen turist sayısında da önemli bir düşüş olduğu vurgulanmıştır.

Novelli vd., (2018), Ebola salgının Gambiya turizmi üzerindeki etkisini analiz etmeyi amaçlamışlardır. $\mathrm{Bu}$ amaçla oluşturulan yirmi araştırma sorusu on dokuz turizm paydaşına yöneltilmiştir. Alınan yanıtlardan elde edilen veriler; kriz önleme ve planlama, stratejik uygulama ve karar, değerlendirme ve geribildirim olmak üzere üç tema altında incelenerek içerik analizine tabii tutulmuştur. Araştırma sonucunda Gambiya'nın olası krizlere karşı proaktif bir turizm krizi yönetim planı olmadığı tespit edilmiştir. Ülkede salgının yayılmasına karşı alınan önlemlerin yanı sıra, salgın sonrasında benzer durumlar için acil durum fonu oluşturulduğu saptanmıştır. Ayrıca, turizm destinasyonlarında kriz hazırlığının ve planlamasının gerekli olduğu vurgusu yapılmıştır.

Çeti ve Ünlüönen (2019), salgın hastalıklar sebebiyle meydana gelen sağlık krizlerinin turizm sektörüne olan etkilerini incelemeyi amaçlamışlardır. Bu bağlamda, ayak ve ağız hastalığı, kuş gribi, domuz gribi, ebola ve SARS salgınlarının turizme olan etkisi, turist sayısı kapsamında değerlendirilmiştir. Araştırma sonucunda, salgın hastalıkların en yaygın gözlendiği ülkelere olan turist talebinde düşüş olduğu belirtilmiştir. Bununla birlikte, salgının görüldüğü yılda turizm destinasyonunun bulunduğu ülkelere gelen turist sayılarının düşük olduğu ancak takip eden yılda salgından önceki gelen turist sayısı rakamlarının aşıldığı ifade edilmiştir.

Joo, H. vd., (2019) çalışmalarında, 2015 Orta Doğu Solunum Sendromu (MERS) salgınının Güney Kore Cumhuriyeti'ndeki konaklama, yiyecek ve içecek ve ulaşım olmak üzere turizm alt sektörleri üzerindeki ekonomik etkisini incelemeyi amaçlamışlardır. Bu doğrultuda, mevsimsel otoregresif entegre hareketli ortalama modeli (SARIMA) kullanılarak üç turizm alt sektörü için MERS salgını sırasında ve sonrasında aylık gelen uluslararası turist sayıları analiz edilmiştir. Sonuç olarak, Güney Kore Cumhuriyeti'nde ziyaretçi sayısının 2,1 milyon azaldığı, turizm gelirinde 2,6 milyar ABD doları kayıp olduğu ve bu rakamın 2015 yılı için GSYİH'nın \%0,2'sini oluşturduğu belirtilmiştir. Tahmini zararın konaklama işletmeleri için 542 milyon ABD doları, yiyecek ve içecek hizmeti sunan işletmeler için 359 milyon ABD doları ve ulaşım sektörlerindeki işletmeler için 106 milyon ABD doları olduğu belirtilmiştir.

Konuyla ilgili yine literatür incelendiğinde, 2020 yllında küresel ölçekte yaşanan Covid-19 salgınının turizm sektörüne etkilerine yönelik olarak da çok hızlı bir şekilde araştırmaların yapılmaya başlandığı da saptanmıştır. 
Akça (2020), Covid-19 salgınının havayolu taşımacılığını ne yönde etkilediğini incelemiş ve söz konusu salgının geçmişte yaşanan diğer krizlerden daha uzun vadeli olarak olumsuz etkiler bırakacağını saptamıştır.

Acar (2020), Covid-19 salgınının dünya turizm sektörü üzerindeki kısa ve uzun vadeli etkilerini tespit etmek amacıyla doküman analizi gerçekleştirmiştir. Analiz sonucunda, sektörün konu bağlamında göstereceği hassasiyet ve iş birliğinin salgının yavaşlatılması için büyük önem taşıdığı, virüsün küresel, ekonomik ve sosyal etkilerinin uzun süre hissedileceği ve turizm sektörünün ortaya çıkan bu olumsuz durumdan doğrudan etkileneceği vurgulanmıştır.

Bahar ve İlal (2020), Covid-19 salgınının turizm sektörünü ekonomik açıdan ne ölçüde etkilediğini kavramsal bağlamda açıklamayı amaçlamışlar ve kriz yönetimi için bir turizm modeli geliştirmişlerdir. Sonuç olarak virüsün turizm sektöründe özellikle istihdam ve gelir kayıpları yaratacağını ifade etmişlerdir.

Bakar ve Rosbi (2020), dünya genelinde Covid-19'un turizm sektörüne etkisini ortaya koymak amacıyla arz ve talep eğrisinden yararlanmışlardır. Oluşturulan eğri sonucunda talep fonksiyonundaki azalmanın, sunulan denge fiyatında ve arz edilen denge miktarında bir azalışa yol açtığ görülmüştür. Oluşturulan matematiksel modellemenin, turizm sektörü üzerindeki ekonomik etkinin dinamik hareketini yönetmesine yardımcı olması bağlamında kullanılması önerilmiştir.

Kalyankar ve Patil (2020), turizm sektörünün ülkelerin ekonomik kalkınmasına katkısını ve Covid-19 salgınının turizm sektörü üzerindeki etkisini analiz etmeyi amaçlamışlardır. Bu bağlamda araştırma sonucunda turizmin sürdürülebilir gelişimi için stratejik bir kalkınma planı oluşturulması, turizmin teşvik edilmesi için yeni bir program geliştirilmesi ve istihdamı artırmak için yerel halkın iş yaşamına dâhil edilmesi önerilmiştir. Ayrıca altyapıya özen gösterilmesi gerektiği, geçmiş ekonomik ve turist akışlarına ilişkin veriler ışığında turizm gelişim düzeyini en yüksek seviyede tutmak için uygulanabilecek tüm önlemlerin düşünülmesi gerekliliği vurgulanmıştır.

Choudhury vd., (2020), Covid-19 salgınının Hindistan turizmine finansal açıdan etkilerini belirlemeye yönelik bir araştırma gerçekleştirmiş̧lerdir. Araştırma sonucunda turizm sektörünün büyük bir darbe aldığı, Hindistan turizm sektörünün 2020 yılında 125 trilyon rupi(Rs) gelir kaybı yaşayacağı, toplam işgücünün \%70'i olan 38 milyon insanın işlerini kaybedecekleri belirtilmiştir. Öte yandan, çeşitli turizm işletmeleriyle yapılan görüşmeler sonucunda Covid-19 salgınının işlerini nasıl etkilediği sorusuna \%61,11 düzeyinde işletmenin yüksek düzeyde olumsuz etkilediği yanıtını verdiği belirlenmiştir.

Karim vd., (2020), Covid-19 salgınının Malezya turizm sektörü üzerinde gelecekte yaratacağ 1 olumsuz etkileri incelemişlerdir. Araştırma sonucunda, Covid-19 salgınının turizm sektörünü olumsuz etkileyeceği ve turizm sektörünün GSYH'ye katkısını düşüreceği vurgulanmıştır.

Priyadarshini (2020), Covid-19 salgınının küresel etkilerini incelemiş ve trend analizi gerçekleştirmiştir. Araştırma sonucunda, salgının 2020 yılında küresel GSYİH'ya olan olumsuz etkisinin en iyi senaryoyla (iki aylık seyahat yasakları ve iç talepteki keskin düşüş) 76,7 milyar ABD doları, en kötü senaryoyla (altı aylık seyahat yasakları ve iç talepteki keskin düşüş) 346,98 milyar ABD doları olacağı belirtilmiştir. Ayrıca, 2020 yılında seyahat ve turizm endüstrisi için küresel gelirin 568,6 milyar ABD doları civarında gerçekleşeceği dolayısıyla 2019'a göre \%17 düzeyinde düşüş olacağı ifade edilmiştir.

Khalilzadeh (2020), Covid-19 salgınının küresel turizm sektörünün geleceğine olan etkilerini incelemiştir. Araştırma sonucunda, Covid-19'un turizm sistemine olan etkilerinin diğer salgınlardan daha olumsuz olduğu; birçok havayolu işletmesinin, otel zincirinin, tema 
parklarının ve kumarhanelerin kapandığı ve binlerce çalışanın geçici olarak işten çıkarıldığg ifade edilmiştir. Öte yandan, salgının sona ermesinden bir veya iki yıl sonra turizm sektörünün iyi olacağ 1 fakat sektörde yapısal ve işlevsel değişmeler gerçekleşeceği belirtilmiştir. Bu değişimlerin beraberinde yerelleşme eğiliminin attıracağı, birçok genç işgücünün istihdam edileceği, turizmin mevcut destinasyonlardan farklı destinasyonlara kayacağı ve yeni havayolu markalarının ortaya çıkabileceği belirtilmiştir.

Hall vd., (2020), salgının turizm sektörüne olan etkilerini araştırmayı amaçlamışlardır. Araştırma sonucunda, Covid-19'un turizm sektöründe değişmelere neden olacağı ve bu bağlamda ülkelerin iç ekonomileri ve eğitim sistemlerini yeniden planlayarak yerel ve daha sürdürülebilir turizm biçimlerine yönelecekleri ve uluslararası turizmin de devam edeceği ifade edilmiştir.

Menegaki (2020), Covid-19 salgınının uluslararası turizm sektörüne olan olumsuz etkilerinden korunmaya yönelik uygulanabilecek stratejileri incelemiştir. Araştırma sonucunda, turistlere onları salgın gibi talihsiz durumlara karşı koruyan sigortaların sunulması, riskli durumlarda hiçbir ceza olmadan tatillerini iptal etme ve ek bir ücret ödemeden yeniden tatil planlayabilme hakkı verilmesi önerilmiştir. İç turizmin daha çabuk toparlanması beklenildiğinden, fiyatların yerli turistler baz alınarak belirlenmesi gerektiği belirtilmiştir. Ayrıca salgının yayılmasını önlemek için turist sayısının azaltılacağı, böylelikle aşırı turizm sorununun en aza ineceği ve daha sürdürülebilir turizm yapısının oluşturulabileceği vurgulanmıştır.

Youssef vd., (2020), Covid-19 salgınının konaklama ve havayolu sektörleri üzerindeki kısa ve uzun vadeli etkilerini incelemişlerdir. Araştırma sonucunda birçok ülkenin karantina sürecini devam ettirmesi sebebi ile havayolları şirketlerinin iflas işaretleri vermeye başlamış olduğu belirtilmiştir. Araştırmada, sanal gerçekliğin gerçek seyahatin yerine kullanılabileceği, sanal turların da önemli ölçüde artacağı vurgulanmıştır. Ayrıca teknolojinin gelecekteki iş seyahatleri davranışlarında değişikliğe sebep olacağı, çoğu insanın seyahat masraflarını karşılayamayacağından uluslararası seyahat yerine yerel seyahatleri tercih edeceği ve gelecekte seyahat seçeneklerinin azalacağı belirtilmiştir. Bununla birlikte, ayakta kalan havayolu şirketlerinin güzergâhlarını küçük bölgesel destinasyonlara çevirecekleri ve bu güzergâhlara az sayıda turist geleceğinden az sayıda konaklama ihtiyacı olacağı ve birçok otel işletmesinin kapanacağı vurgulanmıştır.

Hoque vd., (2020), Covid-19 salgınının Çin'deki turizm sektörüne etkilerini ölçmeyi amaçlamışlardır. Araştırmada ikincil veri araştırma metodolojisi uygulanmış ve bu bağlamda, yayınlanmış çeşitli akademik dergilerden, hükümet belgelerinden, tarihsel kayıtlardan ve istatistiki veri tabanlarından yararlanılmıştır. Araştırma sonucunda, salgının etkisinin uzun vadeli olacağı, salgın nedeniyle yerli ve uluslararası birçok uçuşun iptal edildiği, uçuşların iptal edilmesi sebebiyle havayolu endüstrisinin gelirlerinde ciddi bir şekilde azalma meydana geldiği belirtilmiştir. Araştırmada ayrıca seyahatlerdeki ertelemelerin devam etmesi halinde şirketlerin uzun vadede zarar göreceği ve ayakta kalmakta zorlanacakları belirtilmiştir.

Ulak (2020), Covid-19 salgınının Nepal'deki seyahat hareketliliğine ve turizm sektörüne olan etkisini incelemiştir. Araştırma sonucunda, Mart ve Nisan aylarının Nepal için en verimli turist sezonu olduğu fakat 2020 yılında salgın sebebiyle sektörün küçüldüğü belirtilmiştir. Araştırmada Nepal'de trekking ve rafting acentelerinin, turist taşıma servislerinin, tur ve nehir rehberlerinin, otel ve havayolları işletmelerinin büyük bir istihdam sorunu yaşayacağı belirtilmiştir.

Gössling vd., (2020), Covid-19 salgınının turizm ve küresel değişime etkisini incelemişlerdir. Araştırmada dünyada son 40 yılda global ölçekte bir dizi önemli salgın yaşandığı, turizmin geçmişte de birçok kriz yaşadığ fakat bu krizlerin hiçbirinin turizmin küresel gelişmesinde uzun zamanlı bir azalışa sebep olmadığı ifade edilmiştir. Öte yandan, Covid-19 salgınının turizm 
üzerindeki etkisinin benzersiz olacağı ve turizm sektörü üzerindeki olumsuz etkisinin uzun süreli olacağına dair kanıtların mevcut olduğunu vurgulamıştır.

Nazneen vd., (2020), Covid-19 salgınının turistlerin 12 ay boyunca seyahat etme davranışlarını nasıl etkileyeceğini belirlemek amacıyla bir araştırma gerçekleştirmişlerdir. Bu amaçla hem Çinlilere hem de Çin'de yaşayan yabancllara Çince ve İngilizce olarak online bir anket uygulanmıştır. Araştırma sonucunda salgının turistlerin seyahat konusundaki bilişsel davranışlarını etkilediğini, katılımcıların seyahat etmenin güvenli olmadığını düşündükleri, salgının turistlerin seyahat planlarına ve seyahat alışkanlıklarına etki ettiğini ve seyahat algılarını negatif yönde etkilediğini tespit etmişlerdir. Bununla birlikte, güvenlik ve hijyen algısının turistik ürün satın alma kararlarında etkili bir faktör olacağı vurgulanmıştır.

Strielkowski (2020), turizm sektörü için Covid-19 salgınının olumsuz etkilerinden korunma stratejileri belirlemeyi amaçlamıştır. Araştırma sonucunda, Covid-19 salgınının sektöre etkisinin 2002 yılında meydana gelen SARS salgınının etkisinden daha yıkıcı olacağı ifade edilmiştir. Araştırmada küresel hava yollarının 113 milyar dolar zarara uğrayacağı vurgulanmıştır. Araştırmada ayrıca stratejiler bağlamında, havayolları ve otellere ilk olarak virüsten iyileşmiş olan kişilere hizmet verilmesi ve onlara çeşitli indirim paketleri sunulması önerilmiştir. Enfekte olmuş kişilerin ayırt edilmesi hususunda, modern teknolojinin yardımcı olabileceği ifade edilmiştir. Akıllı karantina ve izleme programlarının Covid-19 salgını sebebi ile kullanılması gerektiği vurgulanmıştır. Araştırmada ayrıca teknolojik çözümlerin maliyetli olacağı ülkeler için ise daha ucuz sağlı izleme programları kullanılabileceği ve söz konusu uygulamalarla uluslararası turizm ve seyahatten ödün vermeden Covid-19'un yayılmasının engellenebileceği ifade edilmiştir.

Ranasinghe vd., (2020), Covid-19 salginının Sri Lanka turizmi üzerinde olan etkilerini incelemişlerdir. Turizmin, Sri Lanka gibi ada ekonomilerine önemli katkısı olduğunu, diğer birçok sektör gibi, turizm alt sektörlerinin de mevcut durumda hiçbir gelir elde edemediği dolayısıyla bu sektörleri korumak adına işletmelere kredi verilmesi ve özellikle otel işletmelerinin karantina hizmeti veren kuruluşlara kiralanarak çalışanların organizasyonlarda kalmaları sağlanması önerilmiştir. Bunun yanında, yerel ve küresel paydaşlarla bilgi paylaşımı ve iş birliği yapılmasına, salgından sonra değişmesi muhtemel görülen tüketici taleplerinin iyice anlaşılmasına, sosyal medya ve kitle iletişim araçlarının sorumlu kullanılmasına, çalışanlara eğitim imkânı vererek süreç için hazırlıklı olmalarının sağlanmasına ve ulusal turizm işletmelerinin küresel düzeydeki turizm işletmeleri ile sürekli iş birliği halinde olmasına tüm paydaşların dikkat etmesi önerilmiştir.

Yukarıda özetlenmeye çalışılan literatür bağlamında salgın hastalıkların küresel ölçekte turizm sektörünü olumsuz etkilediğini ve turizm sektörünün çarpan etkisi nedeniyle de hem yerel hem ulusal hem de küresel ölçekte ekonomiyi de daralttı̆̆ını söylemek mümkündür. 2020 yılı içerisinde salgına dönüşen Covid-19 salgınının etkileri de hemen kendini göstermeye başlamış ve bununla ilgili araştırmalar da gerçekleştirildiği gözlemlenmiştir. Covid-19 salgınının Türk turizm sektörüne ve özellikle otel işletmelerine yönelik etkilerini, alınan veya alınabilecek önlemleri ve işletmelerin yaşadığı olumsuzluklar bağlamında beklentileri yöneticiler açısından ortaya koymayı amaçlayan bu araştırmanın literatüre katkı sağlayacağı düşünülmektedir.

\section{YÖNTEM}

Bu araştırmada otel yöneticilerinin Covid-19 salgınının Dünya ve Türk turizm sektörüne etkisiyle ilgili düşüncelerinin, otel işletmelerinin bu süreçte uyguladıkları stratejilerin, aldıkları önlemlerin ve merkezi hükümet ile yerel yönetimden beklentilerinin değerlendirilmesi amaçlanmıştır. 
Belirlenen amaçlar doğrultusunda araştırmanın örneklemini otel yöneticileri oluşturmaktadır. Nitel araştırma yöntemine göre desenlendirilen çalışmada, amaçlı örneklem yöntemi kullanılmıştır. Amaçlı örneklem yönteminde, "örneği oluşturan katılımcılar, araştırmacının araştırma problemlerine cevap bulacağına inandığı kişilerden oluşmaktadır" (Coşkun vd., 2015:142). Araştırmada veri toplama aracı olarak online anket formu kullanılmıştır. Sorular, salgın dönemi nedeniyle elektronik ortamda katılımcılara gönderilmiştir. Anket formunda katılımcılara sorulan sorular aşağıda sıralanmıştır;

1. Görev yaptığınız işletmede pozisyonunuz nedir?

2. Görev yaptı̆̆ınız işletme kaç yıldızlıdır?

3. Görev yaptığınız işletme hangi şehirde yer almaktadır?

4. Size göre Covid-19 salgınının turizm sektörüne etkileri ne olacaktır?

5. Sizin işletme politikanız doğrultusunda çalışanlarınız ve hedeflediğiniz pazar açısından almış olduğunuz önlemler nelerdir?

6. Salgının Türkiye' de yayılma ihtimaline karşı alternatif planlarınız var mı?

7. Sizin işletme olarak devletten ve yerel yönetimden beklentiniz nelerdir?

8. Sektör ve işletme bazında önerileriniz nelerdir?

Tablo1. Çalıştığı Pozisyona Göre Katılımcı Dağılımı

\begin{tabular}{|l|c|c|}
\hline Pozisyon & Kişi Sayıs1 & $\mathbf{( \% )}$ \\
\hline Genel Müdür & 39 & 37,86 \\
\hline Satış-Pazarlama Müdürü & 7 & 6,80 \\
\hline Satın alma Müdürü & 7 & 6,80 \\
\hline Yiyecek-İ̧ecek Müdürü & 6 & 5,83 \\
\hline Finans Müdürü & 5 & 4,85 \\
\hline İnsan Kaynakları Müdürü & 4 & 3,88 \\
\hline Operasyon Müdürü & 3 & 2,91 \\
\hline Misafir İlişkileri Müdürü & 3 & 2,91 \\
\hline Genel Müdür Yardımcısı & 3 & 2,91 \\
\hline Güvenlik Müdürü & 3 & 2,91 \\
\hline Ön büro Müdürü & 2 & 1,94 \\
\hline CEO & 2 & 1,94 \\
\hline Duty Manager & 2 & 1,94 \\
\hline Genel Koordinatör & 1 & 0,97 \\
\hline Global Finans Direktörü & 1 & 0,97 \\
\hline Yönetim Kurulu Üyesi & 1 & 0,97 \\
\hline Muhasebe Müdürü & 1 & 0,97 \\
\hline Odalar Bölümü Müdürü & 1 & 0,97 \\
\hline Departman Müdürü & 1 & 0,97 \\
\hline Rezervasyon ve Gelir Müdürü & 1 & 0,97 \\
\hline Kalite Müdürü & 1 & 0,97 \\
\hline Ĕgitim Müdürü & 1 & 0,97 \\
\hline Yiyecek-İçecek Müdür Yardımcısı & 0,97 \\
\hline
\end{tabular}




\begin{tabular}{|l|c|c|}
\hline Online Satış Uzmanı & 1 & 0,97 \\
\hline Teknik Müdür Yardımcısı & 1 & 0,97 \\
\hline Villa Müdürü & 1 & 0,97 \\
\hline İşletme Sahibi & 1 & 0,97 \\
\hline Gelirler Stratejisi Müdürü & 1 & 0,97 \\
\hline Maliyet Sorumlusu & 1 & 0,97 \\
\hline Gelirler ve Krediler Sorumlusu & 1 & 0,97 \\
\hline Toplam & $\mathbf{1 0 3}$ & $\mathbf{1 0 0}$ \\
\hline
\end{tabular}

Anket formu, farklı pozisyonlarda görev yapan 180 otel yöneticisine 19 Mayıs - 1 Haziran 2020 tarihleri arasında Linkedin sosyal medya platformu üzerinden gönderilmiştir. Gönderilen anket formlarından verileri eksiksiz olan 103 anket analiz kapsamına alınmıştır. Araştırmada anketlere yanıt veren otel yöneticilerinin pozisyonlarına göre dağılımı Tablo 1'de sunulmuştur.

Araştırmada anket yoluyla elde edilen veriler içerik analizi yöntemi ile analize tabii tutulmuştur. İçerik analizi; "birbirine benzeyen verileri belirli kavramlar ve temalar çerçevesinde bir araya getirmek ve bunları okuyucunun anlayabileceği bir biçimde düzenleyerek yorumlamaktır" (Yıldırım ve Şimşek, 2013). İçerik analizi bağlamında otel yöneticilerinin, salgının makro düzeydeki etkilerine ilişkin düşünceleri ve sektörde faaliyet gösteren işletmelere yönelik mikro düzeydeki öngörüleri, beklentileri ve önerileri değerlendirilmeye çalışılmıştır. Anket formunda oluşturulan sorulara verilen yantlardan elde edilen veriler frekans sıklıkları göz önünde bulundurularak tablolaştırılmış ve bulgular bölümünde sunulmuştur.

\section{BULGULAR}

Araştırmanın bu bölümünde online olarak gönderilen ankete eksiksiz olarak yanıt veren 103 otel yöneticisinin yanıtları incelenmiş ve içerik analizi yöntemi ile analiz edilmiştir. Aşağıda anket formunda yer alan sorulara katılımcılar tarafından verilen yanıtlar yer almaktadır.

Araştırmada ilk olarak otel yöneticilerine işletmedeki görevleri sorulmuştur. Görev dağılımıyla ilgili yanıtlar, yukarıda Tablo 1'de sunulmuştur. Ankete yanıt veren yöneticilerin ağırlıklı olarak "Genel Müdür" pozisyonunda olduğu, diğer yanıt verenlerin ise farklı pozisyonlarda görev aldıkları saptanmıştır.

Araştırmada ikinci olarak görev aldıkları otel işletmesinin sahip olduğu yıldız sayısı sorulmuştur. Bu soruya verilen yanıtların dağılımları Tablo 2' de sunulmaktadır.

Tablo 2. Otel İşletmelerinin Sahip Olduğu Yıldız Sayısına Göre Dağılımı

\begin{tabular}{|c|c|c|}
\hline Yıldız Sayısı & Say1sı & $(\%)$ \\
\hline 5 Yildizlı & 79 & 76,69 \\
\hline 4 Yildizli & 19 & 18,44 \\
\hline 3 Yildizli & 5 & 4,85 \\
\hline 2 Yildizlı & - & - \\
\hline 1 Yildizli & - & - \\
\hline Toplam & 103 & 100 \\
\hline
\end{tabular}


Tablo 2 incelendiğinde, katılımcıların \%76,69'unun 5 yıldızlı, \%18,44'ünün 4 yıldızlı, \%4,85'inin ise 3 yıldızlı otel işletmelerinde çalıştıkları tespit edilmiştir. Katılımcıların hiçbirinin 1 ve 2 yıldızlı otel işletmelerinde görev almadıkları gözlemlenmiştir.

Araştırmada üçüncü olarak katılımcıların yöneticilik yaptıkları otel işletmelerinin faaliyet gösterdiği şehir sorulmuştur. Bu soruya verilen yanıtların dağılımları Tablo 3'de sunulmaktadır. Tablo 3 incelendiğinde \%46.15'lik bir oranla işletmelerin İstanbul'da faaliyet gösterdiği görülmektedir. İstanbul'u, \%13.46'llk bir oranla Antalya ve \%5,77'lik bir oranla İzmir takip etmektedir. 6 işletmenin ise birden fazla şehirde faaliyet gösteren zincir gruba dahil olduğu saptanmıştır. Araştırmaya katılımın genel olarak Marmara ve Akdeniz bölgelerinden katılım sağlandığı gözlemlenmiştir.

Tablo 3. İşletmenin Faaliyet Gösterdiği Şehirlerin Dağılımı

\begin{tabular}{|l|c|c|}
\hline İşletmenin Faaliyet Gösterdiği Şehirler & Sayıs & $\mathbf{( \% )}$ \\
\hline İstanbul & 48 & 46,15 \\
\hline Antalya & 14 & 13,46 \\
\hline İzmir & 6 & 5,77 \\
\hline Birden Fazla Şehirde & 6 & 5,77 \\
\hline Muğla & 5 & 4,81 \\
\hline Ankara & 5 & 4,8 \\
\hline Nevşehir & 5 & 4,81 \\
\hline Mersin & 2 & 1,92 \\
\hline Gaziantep & 2 & 1,92 \\
\hline Balıkesir & 1 & 0,96 \\
\hline Adana & 1 & 0,96 \\
\hline Hatay & 1 & 0,96 \\
\hline Kocaeli & 1 & 0,96 \\
\hline Kayseri & 1 & 0,96 \\
\hline Tokat & 1 & 0,96 \\
\hline Bursa & 1 & 0,96 \\
\hline Sakarya & 1 & 0,96 \\
\hline Tekirdă̆ & 1 & 0,96 \\
\hline Dubai & 1 & 0,96 \\
\hline Toplam & $\mathbf{1 0 3}$ & $\mathbf{1 0 0}$ \\
\hline
\end{tabular}

Araştırmanın dördüncü sorusu, Covid-19 salgınının turizm sektörüne etkilerini katılımcıların bakış açısıyla tespit etmek amacıyla sorulmuştur. Bu sorudan elde edilen bulgular Tablo 4 'te sunulmaktadır. Tablo 4. incelendiğinde, katılımcılara göre Covid-19 salgınının dünya ve turizm sektörüne etkisi bağlamında en çok öne çıkan ifadelerin sektörde yüksek gelir kaybı ve istihdam kaybı olduğu görülmektedir. Otel yöneticileri, yaşanan salgınla birlikte seyahat kısıtlamaları ile sağlık ve güvenlik kaygılarının talebi azaltarak sektörü olumsuz yönde etkileyeceğini ve yüksek miktarlarda gelir kaybına neden olacağını ifade etmişlerdir. Katılımcılar, gelir kaybının yanı sıra en yüksek diğer etkinin istihdam kaybı olacağını belirtmişlerdir. İşletmelerin kısıtlanan 
faaliyetlerinden öncelikle çalışanların etkileneceği, maliyetleri artan işletmelerin daha az personel ile çalışmaya devam edeceği öngörülmektedir. Üçüncü olarak katılımcı cevaplarında sıklıkla ürün ve hizmet standartlarında değişim vurgusu yapıldığı dikkat çekmektedir. Değişen turist talepleri doğrultusunda hizmet ve ürün standartlarının yeniden şekilleneceği ifade edilmiştir. Ayrıca katılımcılar tarafından, salgından en çok etkilenen sektörlerin başında gelen turizmde özellikle yılsonuna kadar ciddi bir daralma yaşanacağı vurgulanmıştır. Katılımcılar genel bağlamda $\% 60$ ile $\% 70$ arasında bir daralma beklediklerini ifade etmişlerdir. Tabloda yer alan ifadelerin yanı sıra, müşteri profilinde değişim, yurtiçi turizm talebinde artış, çalışanların farklı sektörlerde istihdamı, işletmelerin öz sermayelerinin erimesi gibi ifadelerde katılımcılar tarafından vurgulanmıştır.

Tablo 4. Yöneticilere Göre Covid-19 Salgınının Turizm Sektörüne Etkilerinin Dağılımı

\begin{tabular}{|l|c|c|}
\hline İfadeler & Frekans & (\%) \\
\hline Sektörde gelir kaybı & 14 & 9,93 \\
\hline Sektörde istihdam kaybı & 14 & 9,93 \\
\hline Ürün ve hizmet standartlarında değişim & 13 & 9,22 \\
\hline İşletmelerin hijyen standartlarında değişim & 11 & 7,80 \\
\hline Sektörde daralma & 10 & 7,09 \\
\hline İşletme maliyetlerinde artış & 10 & 7,09 \\
\hline İletmelerin devredilmesi/iflası & 9 & 6,38 \\
\hline Talep kaybı & 8 & 5,67 \\
\hline Butik otel/ karavan tatili/çadır tatillerine olan talepte artışs & 6 & 4,26 \\
\hline Kitle turizmine olan talepte düşüş & 5 & 3,55 \\
\hline Turist tercih ve beklentilerinde değişim & 4 & 2,84 \\
\hline Seyahat sıklı̆̆ında azalma & 4 & 2,84 \\
\hline Sektöre yapılan yatırımların durması & 3 & 2,13 \\
\hline Fiyat artısıı & 3 & 2,13 \\
\hline Ulaşım türü tercihlerinde değişim & 3 & 2,13 \\
\hline Diğer ifadeler & 24 & 17,02 \\
\hline Toplam & $\mathbf{1 4 1}$ & $\mathbf{1 0 0}$ \\
\hline
\end{tabular}

Araştırmanın beşinci sorusu, sektörde faaliyet gösteren otel işletmelerinin çalışanları ve hedefledikleri pazar açısından aldıkları önlemleri tespit etmek amacıyla sorulmuştur. Bu sorudan elde edilen bulgular Tablo 5'de sunulmaktadır. Tablo 5'de katılımcilar tarafından verilen yanıtlar incelendiğinde en sık öne çıkan ifadenin "Sağlık Bakanlığı ile Kültür ve Turizm Bakanlığı tarafından yayımlanan genelgelerin maddelerini uygulamak" olduğu görülmektedir. Yöneticiler özellikle işletmelerinin sağlıklı ve güvenilir bir şekilde faaliyetlerine devam edebilmeleri için oluşturulan genelgelerde yer alan maddelere uyum sağladıklarını vurgulamışlardır. Alınan önlemlerin tekrar etme sıklığı incelendiğinde, öne çıkan bir diğer ifadenin çalışanlara verilen Covid-19 eğitimleri ile ilgili olduğu görülmektedir. Ankete yanıt veren yöneticiler, sundukları eğitim imkanları ile salgın ve korunma yöntemleri hakkında çalışanları bilinçlendirmeyi amaçladıklarını ifade etmişlerdir. Bunun yanı sıra yöneticiler, tesislerde sosyal mesafe önlemlerinin alındığına ilişkin ifadeleri sıkça vurgulamışlardır. Veriler incelendiğinde 4 katılımcının "önlem alınmadı" ifadesini, 8 katılımcının "önlemler kesinleşmedi" ifadesini ve 9 katılımcının "önlem alındı" ifadesini kullanması elde edilen bulgular arasında yer almaktadır. 
Tabloda yer alan ifadelerin yanı sıra, fiyatlama politikasında değişiklikler, düşük kapasite ile hizmet vermek, çalışan saatlerinde düzenlemeler yapmak, çalışan sayısını azaltmak, yurtdışı pazardan turist kabul etmemek, çalışan motivasyonuna yönelik çalışmalar gerçekleştirmek, karpayını işletme sermayesine aktarmak, tesisleri kapalı tutmak, uzaktan çalışma planları hazırlamak gibi ifadelerin diğer önlemler içinde yer aldığını söylemek mümkündür.

Tablo 5. Yöneticilerin, Çalışanlar ve Hedefledikleri Pazar Açısından Aldıkları Önlemlerin Dağılımı

\begin{tabular}{|l|c|c|}
\hline İfadeler & Frekans & (\%) \\
\hline Bakanlıkların yayımladığı genelgeleri uygulamak & 23 & 17,16 \\
\hline Çalışanlara Covid-19 ile ilgili eğitim imkanı sunmak & 15 & 11,19 \\
\hline İ̧letme içinde sosyal mesafe önlemleri almak & 14 & 10,45 \\
\hline Sağlıklı Turizm Sertifikasyon Programı'na katılmak & 11 & 8,21 \\
\hline Termal kamera/ateşölçer/ dezenfektan kullanmak & 8 & 5,97 \\
\hline Hijyen önlemlerine yönelik politikalar oluşturmak & 6 & 4,48 \\
\hline İç pazara yönelmek & 6 & 4,48 \\
\hline Tesis kapalı olduğu için önlem alınamadı & 6 & 4,48 \\
\hline İşletme ile ilgili planları sürekli revize etmek & 5 & 3,73 \\
\hline Kısa çalışma ödeneğinden yararlanmak & 5 & 3,73 \\
\hline $\begin{array}{l}\text { Dijital platformlar üzerinden pazarlama çalışmalarını } \\
\text { sürdürmek }\end{array}$ & 4 & 2,99 \\
\hline Hizmet türünde/şeklinde değişikliğe gitmek & 4 & 2,99 \\
\hline İstihdamı korumaya yönelik çalışmalar yapmak & 4 & 2,99 \\
\hline Hedef pazarı değiştirmek & 3 & 2,24 \\
\hline Hedef pazara yönelik pazarlama çalışmaları yapmak & 3 & 2,24 \\
\hline Çalışana koruyucu ekipman temin etmek & 3 & 2,24 \\
\hline Maliyetleri düşürmeye yönelik önlem almak & 3 & 2,24 \\
\hline Diğger & 11 & 8,21 \\
\hline Toplam & $\mathbf{1 3 4}$ & $\mathbf{1 0 0}$ \\
\hline
\end{tabular}

Araştırmanın altıncı sorusu, katılımcıların salgının Türkiye'de yayılma ihtimaline karşı alternatif planlarını tespit etmek amacıyla sorulmuştur. Bu sorudan elde edilen bulgular Tablo 6'da sunulmaktadir.

Tablo 6 incelendiğinde, otel yöneticilerinin önemli bir bölümü tarafından durumla ilgili alternatif bir plan oluşturulmadığı görülmektedir. Salgının yayılma ihtimaline karşı oluşturulan alternatif planların frekans sıklığı incelendiğinde, ikinci olarak işletmeleri hizmete açmamak ifadesi dikkat çekmektedir. Sektörün özelliği gereği, seyahat ve konaklamaların kısıtlandığı durumlarda hizmet verilmesinin mümkün olmadığı katılımcılar tarafından sıkça vurgulanmıştır. Katılımcılar, gelişmeler doğrultusunda gerekli önlemleri alarak ihtiyaç duyulan noktalarda yatırımlarını gerçekleştireceklerini ifade etmişlerdir. Bunun yanı sıra katılımcılar, hali hazırda konaklama tesisi olarak hizmet veren işletmelerin, farklı sektörlerde kullanılabilmesi amacıyla dönüştürülebileceğini belirtmişlerdir. Katılımcılardan 15 tanesinin alternatif bir plan oluşturduklarını ifade ettikleri, ancak konuyla ilgili bilgi vermedikleri gözlemlenmiştir. Tabloda yer verilen ifadelerin yanı sıra; departmanlara verilen ağırlıklarda değişimler yapmak, çalışma 
saatlerini kısaltmak, iç turizme yönelik pazarlama çalışmaları yapmak, mevcut önlemleri sürdürmek gibi ifadelerde yöneticiler tarafından vurgulanmıştır. Bu ifadeler tabloda diğer ifadesi içinde değerlendirilmiştir.

Tablo 6. Yöneticilerin, Salgının Türkiye'de Yayılma İhtimaline Karşı Oluşturdukları Alternatif Planların Dağılımı

\begin{tabular}{|l|c|c|}
\hline İfadeler & Frekans & $\mathbf{( \% )}$ \\
\hline Alternatif plan yok & 29 & 32,22 \\
\hline İşletmeleri hizmete açmamak & 10 & 11,11 \\
\hline $\begin{array}{l}\text { Gelişmeler doğrultusunda gerekli önlemleri almak/ yatırımlar } \\
\text { yapmak }\end{array}$ & 8 & 8,89 \\
\hline Sektör değiştirmek & 6 & 6,67 \\
\hline Kontrollü düşük kapasite ile hizmet vermek & 5 & 5,56 \\
\hline Farklı turizm kollarına yönelmek & 3 & 3,33 \\
\hline $\begin{array}{l}\text { Mümkün olan departmanlarda uzaktan çalışma prosedürleri } \\
\text { uygulamak }\end{array}$ & 3 & 3,33 \\
\hline Maliyetleri düşürmek/yönetmek & 3 & 3,33 \\
\hline Diğer & 23 & 25,56 \\
\hline Toplam & $\mathbf{9 0}$ & $\mathbf{1 0 0}$ \\
\hline
\end{tabular}

Araştırmanın yedinci sorusunda ankete katılan otel yöneticilerinin Covid-19 salgınıla ilgili, turizm sektörüne yönelik devletten ve yerel yönetimden beklentileri tespit edilmeye çalışılmıştır. $\mathrm{Bu}$ sorudan elde edilen bulgular Tablo 7'de sunulmaktadır. Tablo 7 incelendiğinde otel yöneticilerinin devletten ve yerel yönetimden en büyük beklentilerinin vergi indirimleri ve muafiyetleri olduğu görülmektedir. Yöneticiler, durgun bir dönemde vergi yükünün hafifletilmesine ihtiyaç duyduklarını ifade etmişlerdir. Ankete katılan yöneticiler tarafından verilen ikinci en sık yanıtın kısa çalışma ödeneği desteğinin devam etmesi olduğu görülmektedir. Yöneticiler, söz konusu desteğin en az yılsonuna kadar devam ettirilmesi gerektiği görüşünde olduklarını vurgulamışlardır. Ayrıca sektöre özel teşvik tedbirlerinin uygulanması, çalışan haklarını korumak için politikalar oluşturulması ve salgın için uygulanan önlemlerin yoğun denetime tabi tutulması yöneticiler tarafından öne çıkarılan beklentiler olarak saptanmıştır. Tabloda yer alan ifadelerin yanı sıra; Covid-19 ile ilgili harcamaların devlet tarafından karşılanması, seyahat kısıtlamalarının kaldırılması, sertifikasyon aşamasında denetim birimleri ile destek talebi, kiracı- mülk sahipleri arasında arabuluculuk hizmeti ve kredilerin ertelenmesi gibi ifadelerde yöneticiler tarafından vurgulanmıştır. Bu ifadeler tabloda diğer ifadesi içinde değerlendirilmiştir.

Anketin sekizinci sorusunda ise otel yöneticilerinin sektör ve işletme bazında önerileri incelenmeye çalışılmıştır. Bu sorudan elde edilen bulgular Tablo 8' de sunulmaktadır.Tablo 8' de yer alan ifadeler incelendiğinde, "güvenli ülke imajına yönelik pazarlama çalışmaları gerçekleştirilmeli" ifadesinin frekans değeri en yüksek ilk öneri olduğu görülmektedir. Hastalığın diğer turizm ülkelerine nazaran daha az görüldüğü Türkiye'de, bu durumun bir reklam çalışması olarak kullanılması gerektiği ifade edilmiştir. Yöneticiler, eşit frekans sıklığında "nitelikli işgücünün korunması gerektiği" önerisinde bulunmuşlardır. Bu bağlamda maliyetleri düşürmek için istihdamı azaltmanın, gelecek dönemlerde daha büyük problemlere yol açabileceği vurgulanmıştır. Bunun yanı sıra Kültür ve Turizm Bakanlığı tarafından verilen sertifikada ve Sağlık Bakanlığı tarafından yayımlanan genelgede yer alan maddelerin eksiksiz yerine getirilmesi gerektiği önerisi sık önerilen ifadeler arasında yer almaktadır. Tabloda yer alan 
ifadelerin yanı sıra; bulgularda 2021 yılı için ön satışların yapılması, maliyetleri azaltmak için tedbirlerin alınması, sektörün farklı dünya pazarlarına yönelmesi, düşük kapasite ile hizmet sunmaya devam edilmesi, sertifikasyon programının pazarlama aracı olarak kullanılması gibi farklı öneriler de dikkat çekmektedir.

Tablo 7. Yöneticilerin, Devletten ve Yerel Yönetimden Beklentilerinin Dağılımı

\begin{tabular}{|l|c|c|}
\hline İfadeler & Frekans & $\mathbf{( \% )}$ \\
\hline Vergi indirimi/muafiyeti & 18 & 16,98 \\
\hline Kısa çalışma ödeneği desteğinin devam etmesi & 16 & 15,09 \\
\hline $\begin{array}{l}\text { Çalışan haklarının korunması için denetim } \\
\text { mekanizmaları oluşturulması }\end{array}$ & 9 & 8,49 \\
\hline Sektöre yönelik teşvik primleri & 7 & 6,60 \\
\hline Denetim ve kontrollerin sık yapılması & 5 & 4,72 \\
\hline $\begin{array}{l}\text { Dış pazara yönelik tanıtım faaliyetleri } \\
\text { gerçekleştirilmesi }\end{array}$ & 5 & 4,72 \\
\hline Maliyetlerin düşürülmesi & 4 & 3,77 \\
\hline $\begin{array}{l}\text { Alınan kararların kontrolü için yaptırımların } \\
\text { düzenlenmesi }\end{array}$ & 4 & 3,77 \\
\hline $\begin{array}{l}\text { İ turizm talebini artırmak için çalışmalar } \\
\text { gerçekleştirilmesi }\end{array}$ & 3 & 2,83 \\
\hline Diğer & 35 & 33,02 \\
\hline Toplam & $\mathbf{1 0 6}$ & $\mathbf{1 0 0}$ \\
\hline
\end{tabular}

Tablo 8. Yöneticilerin Sektör ve İşletme Bazında Önerilerinin Dağılımı

\begin{tabular}{|l|c|c|}
\hline İfadeler & Frekans & Yüzde(\%) \\
\hline $\begin{array}{l}\text { Güvenli ülke imajına yönelik pazarlama çalışmaları } \\
\text { gerçekleştirilmeli }\end{array}$ & 9 & 8,65 \\
\hline Nitelikli işgücü korunmalı & 9 & 8,65 \\
\hline $\begin{array}{l}\text { Sertifikasyon programına ve yayımlanan genelgelere uyumun } \\
\text { takibi sağlanmalı }\end{array}$ & 8 & 7,69 \\
\hline Sektör çalışanlarına eğitim desteği sağlanmalı & 6 & 5,71 \\
\hline Paydaş işbirliği sağlanarak kalkınma planı oluşturulmalı & 5 & 4,81 \\
\hline Faaliyetler sıkı denetime tabi tutulmalı & 5 & 4,81 \\
\hline Bireysel önlemlere önem verilmeli & 4 & 3,85 \\
\hline İşletmelerde sağlıklı ve güvenilir bir ortam oluşturulmalı & 4 & 3,85 \\
\hline Sektör işbirliği ile fiyatlama kurulu oluşturulmalı & 4 & 3,85 \\
\hline $\begin{array}{l}\text { Çalışmaları dijital şekilde yürütmek için gerekli çalışmalar } \\
\text { yapılmalı }\end{array}$ & 4 & 3,85 \\
\hline Vergi muafiyeti/indirimi talep edilmeli & 4 & 3,85 \\
\hline $\begin{array}{l}\text { Belirsizlik ortamında farklı durumlar için senaryolar } \\
\text { oluşturulmalı }\end{array}$ & 3 & 2,88 \\
\hline Tesisler kapalı tutulmalı & 3 & 2,88 \\
\hline Değişime hızlı şekilde uyum sağlanmalı & 3 & 2,88 \\
\hline Diğer & 33 & 31,73 \\
\hline Toplam & $\mathbf{1 0 4}$ & $\mathbf{1 0 0}$ \\
\hline
\end{tabular}




\section{TARTIŞMA, SONUÇ ve ÖNERILLER}

İnsanlık tarihinde yaşanan salgın hastalıkların sonucunda ekonomik, çevresel, sosyal, politik değişimlerin yaşandığı görülmektedir. Son yüzyılın en önemli salgınlarından biri olarak kabul gören Covid-19 salgınının, her sektörü farklı ölçeklerde etkileyerek aylar süren küresel bir durgunluğa sebep olacağı ve tedavisi bulunmaz ise olumsuz etkilerinin gelecekte uzun bir süre daha devam edeceği tahmin edilmektedir. Salgın; toplumu, ekonomiyi ve turizm sektörünü doğrudan etkisi altına alarak tüketici davranışları, seyahat şekilleri, destinasyon tercihleri gibi birçok konuda değişime yol açmıştır. Süreç izlendiğinde, turizm sektöründe faaliyet gösteren otel işletmeleri üzerinde yapısal ve işlevsel farklılıklar oluştuğu görülmektedir. Söz konusu değişimin, sektöre yön veren yöneticilere ait görüşler bağlamında incelenmesinin önem arz ettiği düşünülmektedir. Bu bağlamda araştırmanın amacı, otel yöneticilerinin bakış açısı ile Covid-19 salgınının turizm sektörüne etkilerinin, konuyla ilgili alınan tedbirlerin ve önerilerin değerlendirilmesi olarak belirlenmiştir. Bu kapsamda online olarak elde edilen 103 anket, içerik analizi yöntemi kullanılarak analiz edilmiştir.

Araştırmada, öncelikle katılımcılara göre Covid-19 salgınının turizm sektörüne etkileri tespit edilmeye çalışılmıştır. Katılımcılar en fazla olarak sektörde yüksek gelir ve istihdam kaybı yaşanacağını ve bu bağlamda sektörün olumsuz etkileneceğini beklediklerini ifade etmişlerdir. Söz konusu bulgular Bahar ve İlal (2020) ve Youssef, Zeqiri ve Dedaj (2020) çalışma sonuçları ile paralellik göstermektedir. Katılımcılar turist beklenti ve talepleri doğrultusunda ürün ve hizmet standartlarında değişim yaşanacağını ve işletmelerin özellikle hijyen prosedürlerinde şeffaf ve yenilikçi bir tavır sergileneceğini de belirtmişlerdir. Çalışmanın bu bulguları Nazneen, Hong ve Din (2020) çalışmasının sonuçları ile benzerlik taşımaktadır. Bununla birlikte katılımcılar tarafından kitle turizminden ziyade kişiselleştirilmiş hizmet sunan işletmelerin daha çok tercih edileceği düşünülmektedir. Elde edilen bu bulgu Khalilzahdeh (2020) çalışmasının sonuçları ile örtüşmektedir. Bulgular incelendiğinde, salgının sektöre olan talebi azalttığı için işletmelerin özellikle ekonomik bağlamda olumsuz etkilendiği ve gelecek dönemlerde de bu olumsuz etkinin devam edeceği söylenebilir. Bununla birlikte genel olarak işletme yöneticilerinin sektör yapısında değişimler olacağını öngördüğünü söylemek mümkündür.

Araştırmada ikinci olarak işletmelerin çalışanlar ve hedefledikleri pazar açısından aldıkları önlemler değerlendirilmeye çalışılmıştır. Katılımcılar tarafından verilen yanıtlar incelendiğinde, sektörde faaliyet gösteren işletmelerde Sağlık Bakanlığı ile Kültür ve Turizm Bakanlığı tarafından yayımlanan genelgeler doğrultusunda önlemler alındığı görülmektedir. Bununla birlikte personelin bilinçlendirilmesi için eğitimler verildiği, sosyal mesafe kurallarının dikkate alınarak hizmetin devam ettirildiği ifade edilmiştir. Katılımcılardan bazıları çalıştıkları işletmelerin Sağlıklı Turizm Sertifikasyon Programı'na dahil olmak için hazırlık sürecinde olduklarını belirtmiştir. Alınan ekonomik önlemler incelendiğinde, işletmelerin devlet tarafından sağlanan Kısa Çalışma Ödeneği'nden yararlandığı, maliyetleri düşürmek için çalışmalar yürüttüğü ve mevcut çalışan sayısını azalttığına dair ifadelerin yer aldığı gözlemlenmiştir. Elde edilen bulgular incelendiğinde, işletmelerin genel bağlamda gelen turiste sağlıklı ve güvenli bir ortam sunmak adına önlemler aldığı saptanmıştır. Bunun yanı sıra, işletmelerin bu belirsiz süreçte faaliyetlerini gerçekleştirmeye devam edebilmek için ekonomik önlemler aldıkları da belirlenmiştir.

Araştırmada üçüncü olarak salgının Türkiye'de yayılma ihtimaline karşı işletmelerin oluşturduğu alternatif planlar değerlendirilmeye çalışılmıştır. İşletmelerin \%32.22'sinin salgının yayılması durumunda alternatif bir planlarının olmadığı saptanmıştır. Diğer alternatif planlar incelendiğinde, işletmelerin hizmete açılmaması ve gelişmeler doğrultusunda planları revize etmek gibi diğer öne çıkan ifadeler vurgulanmıştır. $\mathrm{Bu}$ durumun turistik ürünlerin 
stoklanamaması ve hizmetin üretildiği yerde tüketilmesi gerekliliği gibi sektörün yapısal özelliklerinden kaynaklandığı düşünülmektedir. Bununla birlikte turizm sektörünün salgın bağlamında hazırlıksız yakalandığı ve yaşanan belirsizlik nedeniyle de alternatif plan oluşturmada sorunlar yaşadıklarını söylemek mümkündür. Araştırmada dördüncü olarak işletmelerin devletten ve yerel yönetimden beklentileri tespit edilmeye çalışılmıştır. Bulgular incelendiğinde, işletmelerin devletten en yüksek frekanslı beklentilerinin vergi indirimi/muafiyeti ve kısa çalışma ödeneği desteğinin devam etmesi olduğu görülmüştür. Salgın döneminde faaliyetlerine devam edemeyen ve bu bağlamda gelir sağlayamayan otel işletmeleri, finansal yükümlülüklerini hafifletmek için devletten ekonomik alanda destekler beklemektedir. Ayrıca salgının seyrinin diğer ülkelere göre daha hafif görüldügü Türkiye'de, dış pazara yönelik tanıtım çalışmalarının gerçekleştirilmesi talep edilmiştir. Turistlerin daha sağlıklı bir ortamda hizmet almaları için denetimlerin ve kontrollerin sık yapılması öne çıkan beklentiler arasında yer almaktadir.

Araştırmada son olarak katılımcıların sektör ve işletme bazında önerileri tespit edilmeye çalışılmıştır. Ülkemize gelecek turist sayısının artması için güvenli ülke imajına yönelik pazarlama çalışmalarının yapılması otel yöneticileri tarafından sıkça ifade edilmiştir. Bu süreçte özellikle faaliyetlerine devam edemeyen işletmelerde istihdamın korunması adına harekete geçilmesi gerektiği vurgusu dikkat çekmektedir. Katılımcılar, sektör paydaşlarının birlik içinde hareket ederek etkili kararlar alması ve bir kalkınma planı oluşturulması gerekliliğini vurgulamışlardır. Söz konusu bulgular Acar (2020), Ranasinghe (2020) ve Kalkyankar ve Patil (2020) çalışmalarıyla paralellik göstermektedir.

Genel olarak bulgular değerlendirildiğinde otelcilik alt sektörünün salgına hazırlıksız yakalandığı ve salgının sektöre özellikle ekonomik bağlamda kalıcı olumsuz etkiler bırakacağını söylemek mümkündür. Alternatif planlar, alınan önlemler ve devletten beklentiler sağlıklı, güvenli ve ekonomik açıdan sürdürülebilir bir turizmin gerekliliğini göstermektedir. Daha önce birçok bölgesel salgın ve kriz yaşamış olan turizm sektörünün "yeni normal"e alışma sürecinin sektör paydaşları tarafından dikkatle izlenmesi gerektiği düşünülmektedir. Turizm sektöründe faaliyet gösteren işletmelerin kısa vadeli planlar yerine uzun vadeli ve küresel önlemler alarak hareket etmeleri gerekmektedir. Öngörülemeyen bu krizi atlatabilmek için işletmelerin farklı gelişmeler karşısında farklı senaryolar oluşturmaları bu süreçte ayakta kalabilmeleri açısından önem arz etmektedir. Özellikle 30 Haziran 2020 tarihinde Avrupa Birliği'nin 14 ülkeyi Covid-19 salgını nedeniyle güvenli ülke ilan etmesi ve sınır kapılarını açmasıyla ilgili kararında Türkiye'nin bu listede olmaması, yaz sezonu açısından yabancı turist sayısını oldukça olumsuz şekilde etkileyeceği açıktır. Bu nedenle Kültür ve Turizm Bakanlığı, Dışişleri Bakanlığı ve Sağlık Bakanlığı'nın yurt dışında Türkiye'nin salgın açısından güvenli ülke olarak kabul edilmesi için yoğun bir halkla ilişkiler çalışması yapması önem arz etmektedir. Bununla beraber Türkiye Turizm Yatırımcıları Derneği, Türkiye Otelciler Birliği ve Türkiye Seyahat Acentaları Birliği gibi Türk turizm sektöründeki önemli meslek birliklerinin eşgüdümlü bir şekilde dış pazara yönelik bilgilendirme ve halkla ilişkiler çalışması yapması gerekmektedir. Yine yabancı turist sayısının oldukça azalması ihtimaline karşı Türk otel işletmelerinin iç turizmi canlandıracak tanıtım, pazarlama ve fiyatlama stratejilerini ivedilikle uygulamaya sokması büyük önem arz etmektedir. Ayrıca 2019 yılında dünyanın en büyük tur operatörlerinden birisi olan Thomas Cook'un iflas etmesiyle birlikte alacaklarını tahsil etmede büyük zorluklar içinde olan ve bu bağlamda zaten finansal sıkıntı ve nakit sıkışıklığı yaşayan küçük ve orta ölçekli otel işletmelerinin Covid-19 salgını nedeniyle ilave olarak yaşaması ihtimal ciro, kar ve nakit akışı kaybına karşı devlet tarafından nakdi ve gayri nakdi olarak desteklenmesi gerekmektedir. Bütün bu stratejilerin eşgüdümlü olarak belirlenip uygulanabilmesi için bütün sektör temsilcileri ile turizm 
akademisyenlerinden oluşan bir bilim-sektör kurulunun acil olarak oluşturulmasının son derece önemli olduğu düşünülmektedir.

Araştırma sınırlı sayıda katılımcı ve katılımcıların ifadeleriyle kısıtlıdır. Bununla birlikte sektörde faaliyet gösteren işletmelerin konuyla ilgili geliştirdikleri stratejiler, aldıkları önlemler ve beklentilerin doğrudan otel yöneticilerinin ifadelerinden yararlanarak analiz edilmesi, literatüre katkısı bakımından önem arz etmektedir. Gelecekte daha geniş örneklem ve turizmin farklı alt sektörlerinde gerçekleştirilecek araştırmaların, gelecekte yaşanabilecek benzer krizler için rehber olması bağlamında önemli olacağı düşünülmektedir. Yine Covid-19 salgınının sona ermesi durumunda, salgının turizm sektöründeki işletmelerin yönetimsel, pazarlama ve finansal performansına olan etkilerini belirlemeye yönelik araştırmalar gerçekleştirilebilir.

\section{KAYNAKÇA}

Airports Council International, (2020). Economic Bulletin - ACI World. [Online] https://aci.aero/wpcontent/uploads/2020/03/200401-COVID19-Economic-Impact-Bulletin-FINAL-1.pdf [Erişim Tarihi: 10.04 .20$]$

Bakar, N. A. and Rosbi, S. (2020). Effect of Coronavirus Disease (COVID-19) to Tourism Industry, International Journal of Advanced Engineering Research and Science, 7(4): 189-193.

Beirman, D. (2003). Restoring Tourism Destinations in Crisis: A Strategic Marketing Approach, Riding the Wave of Tourism and Hospitality Research, 1146.

Choudhury, S., Jha, M. K. and Pathak, K. R. (2020). An Empirical Study of The Financial Impact of Covid -19 on The Tourism Industry in India, Purakalawith ISSN 0971-2143 is an UGC CARE Journal, 31(26): 246-255.

Coker, R., Rushton, J., Mounier-Jack, S., Karimuribo, E., Lutumba, P., Kambarage, D., Pfeiffer, D. U., Stark, K., and Rweyemamu, M. (2011). Towards A Conceptual Framework to Support OneHealth Research for Policy on Emerging Zoonoses, The Lancet Infectious Diseases, 11(4), 326-331.

Çeti, B. ve Ünlüönen, K. (2019). Salgın Hastalıklar Sebebiyle Oluşan Krizlerin Turizm Sektörü Üzerindeki Etkisinin Değerlendirilmesi, Ankara Hacı Bayram Veli Üniversitesi Turizm Fakültesi Dergisi, 22(2), 109-128.

Greger, M. (2007). The Human/Animal Interface: Emergence and Resurgence of Zoonotic Infectious Diseases, Critical Reviews in Microbiology, 33(4), 243-299.

Gössling, S., Scott, D. and Hall, C. M. (2020). Pandemics, Tourism and Global Change: A Rapid Assessment of COVID-19, Journal of Sustainable Tourism, 1-20. [Online] https://www. tandfonline.com/doi/epub/10.1080/09669582.2020.1758708?needAccess=true [Erişim Tarihi: 12.05.20].

Hall, C. M., Scott, D. and Gössling, S. (2020). Pandemics, Transformations and Tourism: Be Careful What You Wish For, Tourism Geographies, 1-22. [Online] https://www. tandfonline.com/doi/pdf/10.1080/14616688.2020.1759131?needAccess=true [Erişim Tarihi: 10.05.20].

Hoque, A., Shikha, F. A., Hasanat, M. W., Arif, I. and Hamid, A. B. A. (2020). The Effect of Coronavirus (COVID-19) in the Tourism Industry in China, Asian Journal of Multidisciplinary Studies, 3(1), 52-58.

https://www.bbc.com/turkce/topics/cr50y608n8yt [Erişim Tarihi: 15.04.20]. 
https://www.unwto.org/news/covid-19-world-tourism-remains-at-a-standstill-as-100-ofcountries-impose-restrictions-on-travel [Erişim Tarihi: 15.05.20].

https://wttc.org/News-Article/WTTC-now-estimates-over-100-million-jobs-losses-in-the-Travel\&-Tourism-sector-and-alerts-G20-countries-to-the-scale-of-the-crisis [Erişim Tarihi: 11.05.20].

https://www.iata.org/en/iata-repository/publications/economic-reports/covid-19-deliversunprecedented-shock/ [Erişim Tarihi: 20.05.20].

http://www.turob.com/tr/haberler/str-mart-2020-raporu-dunya-turizmine-buyuk-fatura [Erişim Tarihi: 25.05.20].

https://www.tga.gov.tr/turkiyenin-guvenli-turizm-programi-hakkinda/ [Erişim Tarihi: 08.05.20].

Joo, H., Maskery, B. A., Berro, A. D., Rotz, L. D., Lee, Y. K. and Brown, C. M. (2019). Economic Impact of the 2015 MERS Outbreak on The Republic of Korea's Tourism-Related Industries, Healt hsecurity, 17(2), 100-108.

Kalyankar, M. D. and Patil, P. (2020). Impact of Covid-19 Pandemic on the Tourism Sector, Purakalawith ISSN 0971-2143 is an UGC CARE Journal, 31(8): 611-617.

Karim, W., Haque, A., Anis, Z. and Ulfy, M. A. (2020). The Movement Control Order (MCO) for COVID-19 Crisis and its Impact on Tourism and Hospitality Sector in Malaysia, International Tourism and Hopitality Journal, 3(2): 1-7.

Khalilzadeh, J. (2020). The Future of The Global Tourism System Post Covid-19. [Online] https://business.ecu.edu/wp-content/pv-uploads/sites/152/2020/04/THE-FUTURE-OF-THEGLOBAL-TOURISM-SYSTEM-POST-COVID-19Final.pdf [Erişim Tarihi: 22.06.20].

Kuo, H., Chen, C., Tseng, W., Ju, L. and Huang, B. (2008). Assessing Impacts of SARS and Avian Fluon International Tourism Demand to Asia, Tourism Management, 29, 917-928.

Menegaki, A. N. (2020). Hedging Feasibility Perspectives Against the COVID-19 in the International Tourism Sector, 1-18. [Online] https://www.preprints.org/manuscript/ 202004.0536/v1 [Erişim Tarihi: 22.06.20].

Nazneen, S., Hong, X. and Din, N. U. (2020). Covid-19 Crises and Tourist Travel Risk Perceptions, Available at SSRN 3592321. [Online] https://papers.ssrn.com/sol3/papers.cfm?abstract_id =3592321. [Erişim Tarihi: 05.06.20].

Novelli, M., Burgess, L. G., Jones, A. and Ritchie, B. W. (2018). 'No Ebola...Still Doomed' - The Ebola-Induced Tourism Crisis. Annals of Tourism Research, 70, 76-87.

Page, S., Song, H. and Wu, D. C. (2012). Assessing the Impacts of the Global Economic Crisis and Swine Flu on Inbound Tourism Demand in The United Kingdom, Journal of Travel Research, 51(2), $142-153$.

Pongsiri, M. J., Roman, J., Ezenwa, V. O., Goldberg, T. L., Koren, H. S., Newbold, S. C. and Salkeld, D. J. (2009). Biodiversity Loss Affects Global Disease Ecology, Bioscience, 59(11), 945-954.

Priyadarshini, I. (2020). A Survey on some of the Global Effects of the Covid-19 Pandemic, 1-21. [Online] https://www.researchsquare.com/article/rs-20842/latest.pdf. [Erişim Tarihi: 11.06.20]

Ranasinghe, R., Damunupola, A., Wijesundara, S., Karunarathna, C., Nawarathna, D., Gamage, S., Ranaweera, A. and Idroos, A. A. (2020). Tourism After Corona: Impacts of Covid 19 Pandemic and Way Forward for Tourism, Hotel and Mice Industry in Sri Lanka, 1-19.

Strielkowski, W. (2020). COVID-19 Recovery Strategy for Tourism Industry. [Online] https://www.researchgate.net/profile/Wadim_Strielkowski/publication/340167122_COVID- 
19_recovery_strategy_for_tourism_industry/links/5e7bdcba458515efa0a8fb89/COVID-19recovery-strategy-for-tourism-industry.pdf. [Erişim Tarihi: 10.06.20].

World Health Organization. (2020). Coronavirus Disease 2019 (Covid-19): Situation Report, 51.

Wu, T., Perrings, C., Kinzig, A., Collins, J. P., Minteer, B. A. and Daszak, P. (2017). Economic Growth, Urbanization, Globalization, and the Risks of Emerging Infectious Diseases in China: A Review, Ambio, 46(1), 18-29.

Taubenberger, J. K. and Morens, D. M. (2006). 1918 Influenza: The Mother of All Pandemics, Emerging Infectious Diseases, 12(1), 15-22.

T.C. Sağlık Bakanlığı, Halk Sağlığı Genel Müdürlüğü, (2020). Covid-19 (SARS- CoV-2 Enfeksiyonu) Rehberi (Bilimsel Danışma Kurulu Çalışması) [Online] https://covid19bilgi.saglik.gov.tr/tr/covid-19-rehberi.html. [Erişim Tarihi: 10.04.20].

TÜRSAB, (2020). Korona Virüsü (Covid-19) Sonrası Nasıl Bir Dünya Bizi Bekliyor? Mayıs 2020 Raporu. [Online] https://tursab.org.tr/apps//Files/Content/8b368379-712e-4ca3-842569ae28b9f113.pdf. [Erişim Tarihi: 10.06.20].

Ulak, N. (2020). A Preliminary Study of Novel Coronavirus Disease (Covid-19) Outbreak: A Pandemic Leading Crisis in Tourism Industry of Nepal, Journal of Tourism and Hospitality Education, 10, 108-131.

Youssef, A. B., Zeqiri, A. and Dedaj, B. (2020). Short and Long Run Effects of Covid-19 on the Hospitality Industry and the Potential Effects on Jet Fuel Markets, IAEE Energy Forum, 121-124. [Online] https://www.iaee.org/en/publications/newsletterdl.aspx?id=906 [Erişim Tarihi: 12.06.20]. 